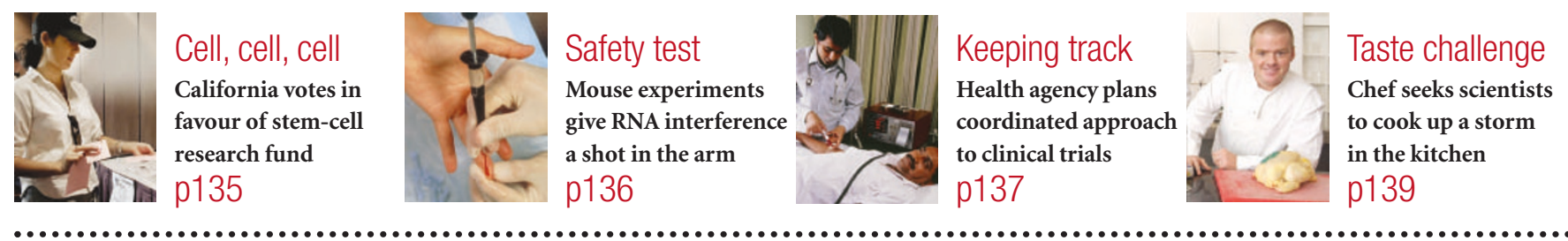

\title{
Watchdogs call academies to account over confilicts of interest
}

\section{Tony Reichhardt, Washington}

The National Academy of Sciences has changed the composition of an expert panel following charges of conflict of interest from environmental watchdogs.

The change in personnel for a group studying the disposal of toxic waste from the coal industry is indicative of the growing strength and sophistication of environmental and health advocacy groups, academy officials say. Several committees have been challenged in the past year alone, leading to resignations and shifts in panel membership.

The academy and its sister organizations, the National Academy of Engineering and the Institute of Medicine, perform about 250 studies a year for the federal government, assembling panels of experts to provide neutral advice on scientific and technical issues.

The Committee on Mine Placement of Coal Combustion Wastes met for the first time on 27 October to consider the question of how coal ash and other waste products should be disposed of in mines. Environmental groups say that the waste, which includes potentially toxic compounds, poses a health risk when it enters groundwater. At stake is whether its disposal should be regulated under the strict guidelines used by the Environmental Protection Agency (EPA) to monitor toxic dumps, or under existing regulations governing mining — as the coal industry would much prefer.

In a letter to the academy on 26 October, the Washington-based Center for Science in the Public Interest (CSPI) and 41 other groups charged that several of the 14 proposed members of the panel have significant ties to the coal industry. The academy has since asked Edward Green, a lawyer at the Washington firm Crowell and Moring who has lobbied for the mining industry, to step down.

Patricia Buffler, an epidemiologist at the University of California, Berkeley, has also resigned - although for scheduling reasons, according to the academy. Buffler has been an adviser to the Electric Power Research Institute in Palo Alto, California, which represents US utility companies.

At least one other member may yet be

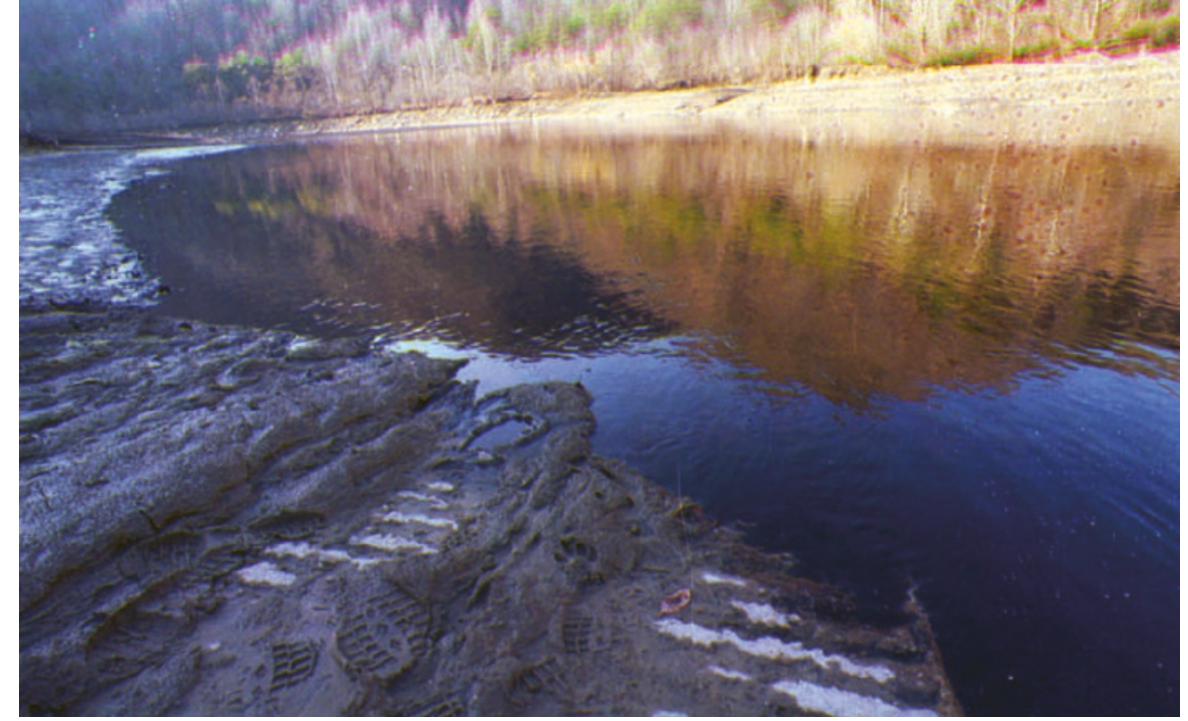

Fouled up: this lake in eastern Kentucky was polluted by waste leaking from a Virginia coal mine.

removed from the committee, says William Colglazier, the academy's executive officer. He adds that all panels are provisional until questions of conflict of interest are settled early in the study process.

Following criticism in 1997, the academy has been reforming the process it uses to provide objective advice to the government (see Nature 390, 104; 1997). As one of several reforms, it began posting the names of proposed panel members 20 days before the start of a study, giving the public time to comment on them.

\section{Keeping an eye}

The CSPI has made a particular point of scrutinizing these lists. The centre's Integrity in Science project was begun four years ago, with funding from the Beldon Fund in New York, "to raise awareness about the role that corporate funding and other corporate interests play in scientific research", according to the group's website.

In January, the CSPI and the Natural Resources Defense Council (NRDC) questioned the make-up of an academy panel investigating the clean-up of a mining region near Coeur d'Alene, Idaho. In March, the CSPI challenged a panel on the EPA's regulation of air pollution partly on the grounds that its chosen chairman, William Happer, a physicist at Princeton University, New Jersey, was well known for his scepticism on global warming. Happer later decided to resign for reasons unrelated to the challenge.

In May, California's two Democratic senators, Barbara Boxer and Dianne Feinstein, wrote to the academy to back the NRDC's protests about potential conflicts of interest held by two members of a committee studying perchlorate in drinking water. Another NRDC challenge, to a panel on toxicity testing of environmental agents, led the academy to acknowledge a conflict of interest for two members, although they were kept on the committee because of their unique expertise.

Colglazier says that such public challenges are welcome, and that the academy process ensures the integrity and neutrality of its studies. In the case of the coal-waste committee, the watchdog groups provided information that the academy's study directors were unaware of when assembling the panel. "Conflict of interest really says nothing at all about the person's morals, it's just a statement of fact," says Colglazier, who nonetheless acknowledges the embarrassment it can cause to scientists removed from a panel. 